\title{
Impact of adiposity on immunological parameters
}

\author{
Impacto da adiposidade nos parâmetros imunológicos
}

Cristiane Martins Moulin', Ivo Marguti², Jean Pierre S. Peron², Luiz Vicente Rizzo ${ }^{3}$, Alfredo Halpern'

\begin{abstract}
Studies evaluating immune function in obese humans and experimental animals indicate that the excess adiposity is associated with impaired in immune responses. Obesity is related to a higher rate of infections and to some types of cancer. Nutritional, metabolic and endocrine factors are implicated in the immunological changes. The adipose tissue directly produces substances with various functions related to immune system. Furthermore, some investigations suggest that certain types of weight reduction strategies can alter the immune function. Nevertheless, long-term studies should be carried out to address whether these changes positively affects the ability of these obese individuals to control infections and tumor development. Arq Bras Endocrinol Metab. 2009;53(2):183-189.

Keywords

Obesity; adipose tissue; immunity; weight loss
\end{abstract}

\section{RESUMO}

Estudos acerca da função imunológica em animais experimentais e humanos obesos indicam que o excesso de adiposidade associa-se ao prejuízo da resposta imune. A obesidade está relacionada a uma taxa maior de infecções e a alguns tipos de câncer. Fatores nutricionais, metabólicos e endócrinos estão implicados nessas alterações imunológicas. O próprio tecido adiposo produz diretamente substâncias com várias funções relacionadas ao sistema imune. Além disso, algumas investigações sugerem que certas estratégias para perda de peso podem alterar a função imune. Entretanto, estudos em longo prazo são necessários para avaliar se tais alterações afetam positivamente a capacidade desses pacientes obesos de controlar infecções e desenvolver tumores. Arq Bras Endocrinol Metab. 2009;53(2):183-189.

Descritores

Obesidade; tecido adiposo; imunidade; perda de peso
${ }^{1}$ Grupo de Obesidade e Síndrome Metabólica, Departamento de Endocrinologia, Hospital das Clínicas da Faculdade de Medicina da Universidade de São Paulo (HC-FMUSP), São Paulo, SP, Brasil ${ }^{2}$ Departamento de Imunologia, Instituto de Ciências Biomédicas, Universidade de São Paulo (USP), São Paulo, SP, Brasil

${ }^{3}$ Departamento de Imunologia, Instituto de Ciências Biomédicas, Universidade de São Paulo (USP) São Paulo, SP, Brasil; Hospital Israelita Albert Einstein (HIAE), São Paulo, SP, Brasil

Correspondence to: Cristiane Martins Moulin Rua Dr. Enéas de Carvalho Aguiar 255 - Prédio dos Ambulatórios, $5^{\circ}$ andar, bloco 4B, sala 11 05403-900 - São Paulo, SP, Brasil crismoulin@yahoo.com.br

Received in Dec/02/2008 Accepted in Feb/18/2009

\section{INTRODUCTION}

$\mathrm{O}$ besity is a worldwide public health problem associated with several comorbidities, such as cardiovascular diseases, diabetes, reproductive disorders, osteoarthritis, gallstones, respiratory disease and some types of cancers (1). Furthermore, obesity has also been associated with decreased immunocompetence (2).

The immune response has two interconnected major branches, innate or natural immunity and acquired or adaptive immunity, which acts in a concerted way to generate protective immunity. Innate immunity includes physical barriers, complement system, macrophagemonocyte system and natural killer (NK) cells. Adap- tive immunity comprises humoral immunity, in which B-lymphocytes produce and secrete antigen-specific antibodies, and cell-mediated immunity, that relies on T-lymphocytes. The T-lymphocytes can be categorized, according to their functions and phenotype, as helper $\mathrm{T}(\mathrm{Th})$ lymphocytes and cytotoxic $\mathrm{T}(\mathrm{Tc})$ lymphocytes. Th-lymphocytes (CD4+) regulate the immune response by producing cytokines that activates macrophages, NK cells and B-lymphocytes, amplifying, in an antigendependent and specific fashion, the immune response. Tc-lymphocytes (CD8+) produce cytokines and mediate cytotoxic, targeting and killing transformed or infected cells (3). 
Obesity can alter innate and adaptive immunity and immunity deterioration is related to the grade of obesity (2).

\section{OBESITY AND IMMUNE FUNCTION RELATIONSHIPS}

The impact of obesity in immunity has been studied in animal models and human subjects. Diet-induced obese animals, considered a comparable model for human obesity, present altered immunological parameters. Lamas and cols. $(4,5)$ observed lymphopenia, lower splenic mitogenic response and a tendency to lower cytotoxic activity of NK cells in diet-induced obese rats. Impaired contact hypersensitivity was also observed in diet-induced obese mice (6).

The impact of obesity in controlling infection clearance has also been assessed in animal models. Diet-induced obese mice have increased mortality compared to lean controls when infected with influenza virus. This findings has been related to a substantial reduction in NK cell cytotoxicity and lower expression of antiviral cytokines, specially type I interferons. In this study, the authors concluded that obesity inhibits the immune system's ability of appropriately responding to influenza infection, and hypothesized that obesity can lead to increased morbidity and mortality due to viral infections (7).

Impaired immune responses have also been suggested to occur in obese humans. Studies indicated that the incidence and severity of certain infections are higher in obese individuals when compared to lean people $(8)$. Weber and cols. (9) showed that obesity was associated with a poor antibody response to hepatitis B plasma vaccine.

Obesity has also been linked to a higher incidence of some types of cancer. The biological mechanisms that link obesity to cancer seem to be multifactorial and to involve a group of metabolic and immunological factors. Several mechanisms by which obesity induces or promotes tumorigenesis have been proposed, including insulin resistance and resultant chronic hyperinsulinaemia, increased bioavailability of steroid hormones and factors released by adipocytes, such as leptin, tumoral necrosis factor- $\alpha$ (TNF- $\alpha$ ) and interleukin (IL)- 6 $(10,11)$. Obesity is related to a condition of chronic inflammation characterized by abnormal production of inflammatory cytokines with local and systemic effects that can contribute to the development of tumors (11). Although local limited inflammation may be involved in the initiation of immune responses, excessive inflammation may promote tumor progression in steady-state conditions (12). Chronic overproduction of reactive oxygen species and cytokines related to obesity by inflammatory cells can induce mutagenic changes and DNA damage, thus contributing to cancer development (11). Finally, the pro-inflammatory cytokines can exacerbate the insulin resistance (10).

Data from literature show differences in immune response between obese and non-obese individuals. Obesity is related to higher neutrophil, monocyte as well as total leukocyte counts (13) and to lower lymphocyte responses to mitogens (14-16). Chandra and Kutty (16) found lower lymphoproliferative response to mitogens, impairment of delayed cutaneous hypersensitivity and a decrease in intracellular bacterial killing capacity by neutrophils in obese children and adolescents. Moriguchi and cols. (17) proposed that the decreased lymphoproliferative response observed in obese rats may be, in part, due to decreased glucose uptake as the main energy source for proliferation of lymphocytes. These authors showed that obese rats have a decreased expression of glucose transporter 1 (GLUT-1), which is expressed on the immune cells membranes after mitogen stimulation. However, further investigation is needed to determine if this is the case in humans as well.

Few studies have evaluated specific parameters of immunity in patients with grade III obesity. Studies from the 1980's described that severely obese individuals have lower maturation of monocytes into macrophages (18) and reduced polymorphonuclear (PMN) bactericidal capacity (19). Differences were also observed in surface markers expressed by monocytes, neutrophils and lymphocytes when patients with grade III obesity were compared to controls individuals with normal weight $(20)$.

\section{ADIPOSE TISSUE AS A PRO-INFLAMMATORY ORGAN}

Adipose tissue has not only been recognized as a multifunctional organ, which plays an important role not only as an energy storage organ, but also exerting important endocrine and immune functions. Various active molecules released by adipocytes, such as IL- 6 , TNF- $\alpha$, and leptin, may act on immune cells leading to local and systemic inflammation $(21,22)$. Several lines of evidence suggest that preadipocytes could function as macrophages-like cells, supporting the idea of a direct involvement of adipose tissue in inflammatory processes (23). Moreover, it has been estimated that the percentage of mac- 
rophages in adipose tissue ranges from less than $10 \%$ in lean mice and humans to 40 to $50 \%$ in obese humans (24). Inflammatory cytokines, as IL- 6 and TNF- $\alpha$, seem to be produced by the infiltrating macrophages in the adipose tissue (24). CC-chemokine ligand 2 (CCL2), produced by adipocytes, has recently been identified as a potential contributing factor to macrophage infiltration into adipose tissue (21). These events might perpetuate a vicious cycle of macrophage recruitment and production of pro-inflammatory cytokines.

The biological activities of IL- 6 include the activation of immune cells and the regulation of acute-phase response, which involves the hepatic synthesis of inflammatory mediators. Furthermore, IL-6 has stimulatory actions on the hypothalamic-pituitary-adrenal axis, taking part as mediator of metabolic and immune responses (25). IL-6 decreases lipoprotein lipase activity, increasing macrophage uptake of lipids and contributing to the progression of atheroma plaque (25). As much as one third of total plasma IL- 6 has been estimated to derive from adipose tissue (22). As IL-6 is believed to be the major regulator of hepatic acute phase response, and adipose tissue produces large amounts of this cytokine, it is conceivable to hypothesize that obesity can resemble a low-grade inflammatory state (25). TNF- $\alpha$ has also been involved in the activation of immune response (3). Studies indicate a role for TNF- $\alpha$ in obesity-linked insulin resistance, thus it seems to be involved in the pathogenesis of diabetes and dyslipidemia (26).

Leptin is the most studied adipocyte-derived hormone and body mass index (BMI) is the main determinant of circulating leptin in the body (27). Its functional receptor is expressed not only in the hypothalamus, where it regulates energy homeostasis and neuroendocrine function, but also in several cell types of innate and adaptive immunity (28). In vitro studies using both animal and human cells with complete leptin deficiency have demonstrated the role of leptin in modulating immune function. Leptin can stimulate the development of myeloid cells, activate monocytes and macrophages, modulate dendritic cells and NK cells, and influence the proliferation and cytokine production by the T-lymphocytes with a shift toward Thl phenotype immune response (28). Chan and cols. (29) showed that the complete leptin depletion from human serum with anti-human leptin antibody suppresses the proliferative response of T-lymphocytes in vitro and that this phenomenon can be reverted by leptin replacement.

Macrophages from mice lacking leptin or its functional receptor have reduced phagocitic function (30).
Furthermore, T-lymphocytes responses are impaired in these mice $(17,31)$, which also present lymphoid organs atrophy (32) and impaired function of dendritic cells (33). In cases of leptin deficiency, these alterations are reversible with leptin administration $(30,32,33)$. Similarly, patients with obesity due to the rare congenital leptin deficiency seem to have increased the susceptibility to infection (28). The administration of recombinant human leptin to two children with this cause of obesity restored the proliferative response and cytokine production by lymphocytes (34).

Mito and cols. (35) observed that starvation with or without exogenous leptin administration has distinct effects on immunological parameters in diet-induced obese mice and lean controls. Starvation of the control mice dramatically reduced the weights of immune organs, cytokine production and increased proliferation of cultured splenocytes. However, these levels returned to those of the free-feeding group upon exogenous leptin administration. The effects of exogenous leptin, on the other hand, were not observed in obese mice. It is possible that immune cells from obese individuals acquire leptin resistance, rendering them refractory to leptin stimulation despite its high concentration in the serum. A recent study showed that the stimulatory effect of leptin on NK cells activity is abrogated in diet-induced obese mice (36). It has been demonstrated that these animals have lower activation of post-receptor signaling components following an in vivo leptin challenge. This study suggests that the underlying mechanism for leptin resistance in NK cells from obese experimental animals is a defect in Janus tyrosine kinase (JAK2)mediated activation of signal transducer and activator of transcription 3 (STAT3). Other authors have shown that STAT3-mediated signaling in T-lymphocytes is decreased in a diet-induced mouse model of obesity (37). In conclusion, these studies demonstrate that leptin resistence associated to diet-induced obesity can occur not only at hypothalamic level, but also at immune cells.

\section{EFFECTS OF NUTRIENTS ON IMMUNE SYSTEM}

Excess of nutrients can affect immune responses directly and indirectly, by affecting metabolic and endocrine status of the individual. Lymphocytes and NK cells are cells with high metabolism, and with extreme dependency on glucose to get energy and to glycosilate their surface receptors (38). Moreover, these cells can be affected by modified lipoprotein to secrete vasoactives 
factors (39). Dietary lipids have an important regulatory action in the immune system, including modulation of eicosanoid synthesis, alterations in plasma membrane structure, and changes in lipoprotein metabolism (40). High fat intake may be harmful to lymphocytes function. A study showed that a diet rich in saturated fat impairs the response of both naive and antigen-experienced T-cells (41). Barone and cols. (42) suggested that lowering the amount of fat in diet may improve the NKcell cytotoxic activity. It was observed that obese subjects usually have a higher fat intake (43), which can contribute to the immune dysfunction in this population.

\section{EFFECTS OF WEIGHT LOSS IN THE IMMUNE FUNCTION}

\section{Weight loss induced by diet}

It has been suggested that certain types of weight reduction strategies produce alterations in immune function. Diet-induced overweight rats have increased Th cells percentage, proliferative response of splenocytes and increased NK-mediated cytotoxic activity against target cells one month after energy restriction (5). Weight-reducing diets are the most common treatment for obesity. Their effects on immunocompetence have been reported in some studies, but the results are controversial.

Studies have pointed out to an improvement of immunological parameters after weight loss. Subjects examined after weight loss, induced by 14-days fast, showed improvement in serum immunoglobulin levels, delayed-type hypersensitivity (DTH) response, bactericidal capacity of blood monocytes and NK cell cytotoxic activity, although there was a decrease in mitogen-stimulated lymphocyte proliferation (44). Tanaka and cols. $(14,15)$, on the other hand, showed that mitogen-stimulated lymphocyte proliferation, which was suppressed in obese patients, was restored after weight loss induced by very low calorie diet (VLCD). The majority of the reports suggest that caloric restriction improves parameters of immunity such as $\mathrm{T}$ cell responses to mitogens, NK cell activity and the ability of mononuclear cells to produce pro-inflammatory cytokines (45).

In contrast, some studies have reported that weight loss is associated with reduction in some aspects of immune function. Caloric restriction for three months resulted in decreased number of circulating NK cells, immunoglobulin (Ig) G, IgA and C3 factor of complement in a cohort of overweight women (46). Suppression of NK cell activity, without reduction of circulat- ing NK cells, was observed in obese women submitted to a eight-week $950 \mathrm{kcal} /$ day diet (47). Reduction in mitogen-stimulated lymphocyte proliferation was referred six months after VLCD (48) and after a 12-week moderate energetic restriction $(1200-1300 \mathrm{kcal})(13)$. Field and cols. (48) also observed a significant decrease in the percentage of Th cells and a drop in the CD4+/ $\mathrm{CD} 8+$ ratio during VLCD. These parameters returned to baseline values upon refeeding. Differences in the assays, characteristics of subjects studied, type and duration of diet employed make it difficult to compare the available data.

\section{Weight loss induced by surgery}

Surgical treatment is currently the most effective therapy to promote and maintain weight loss in severely obese patients. Several bariatric procedures are available and the therapeutic success is variable depending on the employed technique. These surgeries promote weight loss by two main mechanisms: restriction of food intake and food malabsorption (49).

Jejunoileal bypass, also called intestinal bypass, was a purely malabsorptive procedure employed between the 60 's and the 80 's. This technique induced serious complications such as hepatic failure, immune complex arthritis, nephrolithiasis and deficiency of vitamins and minerals, being replaced by improved ones later on. Two studies reported improvement in some aspects of immune function after this surgery. Palmblad and cols. (19) showed an increase in PMN bactericidal capacity and Hallberg and cols. (50) observed improvement in DTH. Nevertheless, there are reports of unusual fungal infections following this procedure (51).

Restrictive procedures, such as vertical banded gastroplasty (VBG) and adjustable gastric banding (AGB), promote weight loss by physical restriction of food intake and induction of satiety. Studies described a decrease in PMN and lymphocytes counts following AGB $(52,53)$. Decrease in acute phase proteins was observed six months after AGB (52). Through another study, van Dielen and cols. (54) showed that soluble TNF receptors and acute phase proteins remained elevated for at least six months after gastric restrictive surgery, decreasing significantly 24 months after the intervention. Reduction of IL-3 and TNF- $\alpha$ serum levels were observed six months after weight loss induced by VBG (55).

Higher rates of successful weight loss are obtained with combined procedures that consist in decreasing the 
gastric capacity associated with gastroenteric bypass. The Roux-en-Y gastric bypass (RYGB) is currently the most commonly performed bariatric surgery, and it appears to be more effective in inducing and maintaining a satisfactory weight loss, with lower rates of complications (49).

The majority of studies addressing the effect of bariatric surgery on immune function have focused on inflammation markers. A recent study with ten women that underwent biliopancreatic bypass observed, 36 months after surgey, a decline in reactive $\mathrm{C}$ protein (RCP), IL-6 and $\alpha$-defensins levels, with no difference in TNF- $\alpha$ levels (56). McAuliffe and cols. (57) observed an increase in blood monocytes and a reduction in circulating dentritic cells until 28 days after RYGB. Vilarrasa and cols. (58) found decreased IL-18, TNF- $\alpha$ receptors and RCP serum levels one year after gastric bypass. The group of Cottam (20) found higher expression of CD95 per T cell, a molecule involved in induction of apoptosis, and lower CD62L (L-selectin) expression, in severely obese patients when compared to controls with ideal weight, and reduction and increase, respectively, of these cellular markers one year after RYGB. The decreased levels of L-selectin might impair migration and recirculation of lymphocytes. Cottam and cols. (20) did not observed any modifications in cell populations of $\mathrm{B}, \mathrm{T}$ and NK cells until one year after surgery. In another study, the effects of excessive adiposity and weight loss on macrophage chemoattractant protein-1 (MCP-1) and interferon (IFN)- $\gamma$, which are important components of immune response to infectious pathogens, production by PBMC were evaluated in severely obese patients before and one year after RYGB. It was observed that the concentration of these molecules, which were lower in obese patients than in age-matched lean subjects, were restored after weight loss induced by surgery (59).

Our group addressed the functional status of NK cells before and six months after RYGB. We demonstrated that in 28 patients with grade III obesity, NK cell activity is enhanced six months after the surgery, when the patients had lost in average $26 \%$ of initial weight. We have also shown that severely obese patients have a significant decrease in NK cells activity in comparison to normal individuals matched for age and gender. This decrease could not be subscribed to a decrease in the numbers of circulating NK cells since the individual numbers as well as the averages were similar, prior to and six months after surgery. Furthermore, we found that the PBMC production of cytokines involved in modulating NK cells activity, as IL-12, IL-18 and IFN- $\gamma(60)$, increased significantly after surgery, which suggests a link between these two parameters (NK cells activity and specific cytokine modulation) (Moulin and cols., unpublished data).

Natural killer (NK) cells are innate immunity cells involved in the control of cancer and infections (3). Although we have not studied the clinical outcomes but rather the effect of obesity on the functional status of NK cells, it is important to notice the correlation between low NK cytotoxic activity, and a higher incidence of tumors and infections in obese subjects. Therefore, we propose that the impaired NK cells cytotoxic activity and cytokines production observed in patients with severe obesity can be one mechanism involved in their propensity to developing cancer and infections. Our data also showed that the functional status of NK cells can be restored upon weight loss, demonstrating that the weight loss induced by bariatric surgery can positively and significantly impact these factors. However, long-term studies should be performed to address whether these changes positively affects the ability of these subjects to control infections and tumor development.

\section{CONCLUSIONS}

Obesity is associated with the impairment of immune response. Epidemiological data indicate a higher susceptibility of obese individuals to infectious diseases and cancer. Therefore, it is conceivable that obesity alters immunity culminating in secondary diseases. Furthermore, many obese patients have alterations of glycidic and lipidic metabolism, which can impair lymphocytes and NK cells function. Finally, the adipose tissue, besides being an endocrine organ, produces substances with various functions that are related to immune system.

The exact mechanism responsible for alterations in the immune system of obese patients is unknown, but can be related to the negative effects of altered nutritional, metabolic, endocrine, and psychological status on immune cells function. Weight reduction has a profound effect on many of these variables. Probably, the improvement of the physiological milieu contributes to an amelioration of immune function after weight loss.

Acknowledgements: Our research was supported by grants of Fundação de Amparo à Pesquisa do Estado de São Paulo (FAPESP).

Disclosure No potential conflict of interest relevant to this article was reported. 


\section{REFERENCES}

1. WHO Consultation on obesity. Obesity: preventing and managing the global epidemic. WHOTech Rep Series no 894. Geneva, Switzerland: World Health Organization; 2000.

2. Martí A, Marcos A, Martínez JA. Obesity and immune function relationships. Obes Rev. 2001;2(2):131-40.

3. Janeway CA, Travers P, Walport M, Sholmchik MJ. Immunobiology: the immune system in health and disease. 6th edition. Garland Science Publishing Inc.: NewYork; 2005.

4. Lamas O, Martinez JA, Marti A.T helper lymphopenia and decreased mitogenic response in cafeteria diet-induced obese rats. Nutr Res. 2002;22:496-507.

5. Lamas O, Martinez JA, Marti A. Energy restriction restores the impaired immune response in overweight (cafeteria) rats. J Nutr Biochem. 2004;15(7):418-25.

6. Katagiri K, Arakawa S, Kurahashi R, Hatano Y. Impaired contact hypersensitivity in diet-induced obese mice. J Dermatol Sci. 2007;46(2):117-26.

7. Smith AG, Sheridan PA, Harp JB, Beck MA. Diet-induced obese mice have increased mortality and altered immune responses when infected with influenza virus. J Nutr. 2007;137(5):1236-43.

8. Falagas ME, Kompoti M. Obesity and infection. Lancet Infect Dis. 2006;6(7):438-46.

9. Weber DJ, Rutala WA, Samsa GP, Santimaw JE, Lemon SM. Obesity as a predictor of poor antibody response to hepatitis $B$ plasma vaccine. JAMA. 1985;254(22):3187-9.

10. Calle EE, Kaaks R. Overweight, obesity and cancer: epidemiological evidence and proposed mechanisms. Nat Rev Cancer. 2004;4(8):579-91.

11. Ceschi M, Gutzwiller F, Moch H, Eichholzer M, Probst-Hensch NM. Epidemiology and pathophysiology of obesity as cause of cancer. Swiss Med Wkly. 2007;137(3-4):50-6.

12. Kim R, Emi M, Tanabe K. Cancer immunoediting from immune surveillance to immune escape. Immunology. 2007;121(1):1-14.

13. Nieman DC, Nehlsen-Cannarella SL, Henson DA, Butterworth DE, Fagoaga OR, Warren BJ, et al. Immune response to obesity and moderate weight loss. Int J Obes. 1996;20(4):353-60.

14. Tanaka $S$, Inoue $S$, Isoda $F$, Waseda $M$, Ishihara M, Yamakawa T, et al. Impaired immunity in obesity: suppressed but reversible lymphocyte responsiveness. Int J Obes. 1993;17(11):631-6.

15. Tanaka $S$, Isoda F, Ishihara $Y$, Kimura M, Yamakawa T. T Iymphopaenia in relation to body mass index and TNF- $\alpha$ in human obesity: adequate weight reduction can be corrective. Clin Endocrinol. 2001;54(3):347-54.

16. Chandra RK, Kutty KM. Immunocompetence in obesity. Acta Paediatr Scand. 1980;69(1):25-30.

17. Moriguchi $S$, Kato M, Sakai K, Yamamoto S, Shimizu E. Decreased mitogen response of splenic lymphocytes in obese Zucker rats is associated with the decreased expression of glucose transporter 1 (GLUT-1). Am J Clin Nutr. 1998;67(6):1124-9.

18. Krishnan EC, Trost L, Aarons S, Jewell WR. Study of function and maturation of monocytes in morbidly obese individuals. J Surg Res. 1982;33(2):89-97.

19. Palmblad J, Hallberg D, Engsted L. Polymorphonuclear (PMN) function after small intestinal shunt operation for morbid obesity. Br J Haematol. 1980;44(1):101-8.

20. Cottam DR, Schaefer PA, Shaftan GW, Angus LD. Dysfunctional immune-privilege in morbid obesity: implications and effect of gastric bypass surgery. Obes Surg. 2003;13(1):49-57.

21. Tilg H, Moschen AR. Adipocytokines: mediators linking adipose tissue, inflammation and immunity. Nat Rev Immunol. 2006;6(10):772-83.

22. Fhühbeck G, Gómez-Ambrosi J, Muruzábal FJ, Burrell MA. The adipocyte: a model for integration of endocrine and metabolic signaling in energy metabolism regulation. Am J Physiol Endocrinol Metab. 2001;280(6):E827-47.

23. Cousin B, Munoz O, Andre M, Fontanilles AM, Dani C, Cousin JL, et al. A role for preadipocytes as macrophage-like cells. FASEB J. 1999;13(2):305-12.

24. Weisberg SP, McCann D, Desai M, Rosenbaum M, Leibel RL, Ferrante $\mathrm{Jr}$ AW. Obesity is associated with macrophage accumulation in adipose tissue. J Clin Invest. 2003;112 (12):1796-808.

25. Yudkin JS, Kumari M, Humphries SE, Mohamed-Ali V. Inflammation, obesity, stress and coronary heart disease: is interleukin-6 the link? Atherosclerosis. 2000;148(2):209-214.

26. Hotamisligil GS, Shargill NS, Spiegelman BM. Adipose expression of tumor necrosis factor- : direct role in obesity-linked insulin resistance. Science. 1993;259(5091):87-91.

27. Geloneze B, Tambascia MA, Pareja JC, Repetto EM, Magna LA, Pereira SG. Serum leptin levels after bariatric surgery across a range of glucose tolerance from normal to diabetes. Obes Surg. 2001;11(6):693-8.

28. Matarese G, Moschos S, Mantzoros CS. Leptin in immunology. J Immunol. 2005;174(6):3137-42.

29. Chan JL, Matarese G, Shetty GK, Raciti P, Kelesidis I, Aufiero D, et al. Differential regulation of metabolic, neuroendocrine, and immune function by leptin in humans. PNAS. 2006;103(22):8481-6.

30. Loffreda S, Yang SQ, Lin HZ, Karp CL, Brengman ML, Wang DJ, et al. Leptin regulates proinflammatory immune responses. FASEB J. 1998;12(1):57-65.

31. Tanaka S, Isoda F, Yamakawa T, Ishihara M, Sekihara H. T Iymphopenia in genetically obese rats. Clin Immunol Immunopathol. 1998;86(2):219-225.

32. Hick RW, Gruver AL, Ventevogel MS, Haynes BF, Sempowski GD. Leptin selectively augments thymopoiesis in leptin deficiency and lipopolysaccharide-induced thymic atrophy. J Immunol. 2006;177(1):169-76.

33. Macia L, Delacre M, Abboud G, OukTS, Delanoye A, Verwaerde $C$, et al. Impairment of dendritic cell functionality and steady-state number in obese mice. J Immunol. 2006;177(9):5997-6006.

34. Faroogi IS, Matarese G, Lord GM, Keogh JM, Lawrence E, Agwu $C$, et al. Beneficial effects of leptin on obesity, $T$ cell hyporesponsiveness, and neuroendocrine/metabolic dysfunction of human congenital leptin deficiency. J Clin Invest. 2002;110(8):1093-103.

35. Mito N, Yoshino H, Hosoda T, Sato K. Analysis of effect of leptin on immune function in vivo using diet-induced obese mice. J Endocrinol. 2003;180(1):167-73.

36. Nave H, Mueller G, Siegmund B, Jacobs R, Stroh T, Schueler U, et al. Resistance of JAK-2 dependent leptin signaling in NK cells: a novel mechanism of NK cell dysfunction in diet-induced obesity. Endocrinology. 2008;149(7):3370-8.

37. Papathanassoglou E, El-Haschimi K, Li XC, Matarese G, Strom $T$, Mantzoros C. Leptin receptor expression and signaling in lymphocytes: kinetics during lymphocyte activation, role in lymphocyte survival, and response to high fat diet in mice. J Immunol. 2006;176(12):7745-52.

38. Rudd PM, Elliott T, Cresswell P, Wilson IA, Dwek RA. Glycosylation and the immune system. Science. 2001;291(5512):2370-6.

39. Mol MJ, Demacker PN, Stalenhoef AF. The role of modification of lipoproteins and of the immune system in early atherogenesis. Neth J Med. 1993;43(1-2):83-90.

40. de Pablo MA, Alvarez de Cienfuegos G. Modulatory effects of dietary lipids on immune system functions. Immunol Cell Biol. 2000;78(1):31-9.

41. Verwaerde C, Delanoye A, Macia L, Tailleux A, Wolowczuk I. Influence of high-fat feeding on both naive and antigen-experienced T-cell immune response in D010.11 mice. Scand J Immunol. 2006;64(5):457-66. 
42. Barone J, Hebert JR, Reddy MM. Dietary fat and natural-killer-cell activity. Am J Clin Nutr. 1989;50(4):861-7.

43. Miller WC, Lindeman AK, Wallace J, Niederpruem M. Diet composition, energy intake and exercise in relation to body fat in men and women. Am J Clin Nutr. 1990;52(3):426-30.

44. Wing EJ, Stanko RT, Winkelstein A, Adibi SA. Fasting-enhanced immune effector mechanisms in obese subjects. Am J Med.1983;75(1):91-6.

45. Dixit VD. Adipose-immune interactions during obesity and caloric restriction: reciprocal mechanisms regulating immunity and health span. J Leukoc Biol. 2008;84(4):1-11.

46. Kelley DS, Daudu PA, Branch LB, Johnson HL, Taylor PC, Mackey $B$. Energy restriction decreases number of circulating natural killer and serum levels of immunoglobulins in overweight women. Eur J Clin Nutr. 1994;48(1):9-18.

47. Scanga $C B$, Verde $T J$, Paolone $A M$, Andersen RE, Wadden TA. Effects of weight loss and exercise training on natural killer cell activity in obese women. Med Sci Sports Exerc. 1998;30(12):1666-71.

48. Field CJ, Gougeon R, Marliss EB. Changes in circulating leukocytes and mitogen responses during very-low-energy all-protein reducing diets. Am J Clin Nutr. 1991;54(1):123-9.

49. Herron DM. The surgical management of severe obesity. The Mount Sinai J Med. 2004;71(1):63-71.

50. Hallberg D, Nilsson BS, Backman L. Immunological function in patients operated on with small intestinal shunts for morbid obesity. Scand J Gastroenterol. 1976;11(1):41-8.

51. Tustin AW, Kaiser AB, Bradsher RW, Herrington JL. Unusual fungal infections following jejunoileal bypass surgery. Arch Intern Med. 1980;140(5):643-5.

52. Hanusch-Enserer U, Cauza E, Spak M, Dunky A, Rosen HR, Wolf $\mathrm{H}$, et al. Acute-phase response and immunological markers in morbid obese patients and patients following adjustable gastric banding. Int J Obes Relat Metab Disord. 2003;27(3):355-61.

53. Dixon JB, O'Brien PE. Obesity and the white blood cell count: changes with sustained weight loss. Obes Surg. 2006;16(3):251-7.

54. van Dielen FM, Buurman WA, Hadfoune M, Nijhuis J, Greve JW. Macrophage inhibitory factor, plasminogen activator inhibitor-1, other acute phase proteins, and inflammatory mediators normalize as a result of weight loss in morbidly obese subjects treated with gastric restrictive surgery. J Clin Endocrinol Metab. 2004;89(8):4062-8.

55. Kyzer S, Binyamini J, Chaimoff C, Fishman P.The effect of surgically induced weight reduction on the serum levels of the cytokines: interleukin-3 and tumor necrosis factor. Obes Surg. 1999;9(3):229-34.

56. Manco M, Fernadez-Real JM, Equitani F, Vendrell J, Mora MEV, Nanni G, et al. Effect of massive weight loss on inflammatory adipocytokines and the innate immune system in morbidly obese women. J Clin Endocrinol Metab. 2007;92(2):483-90.

57. McAuliffe PF, Efron PA, Scumpia PO, Uchida T, Mutschlecner SC, Rout WR, et al. Varying blood monocyte and dendritic cell responses after laparoscopic versus open gastric bypass surgery. Obes Surg. 2005;15(10):1424-31.

58. Vilarrasa N, Vendrell J, Sánchez-Santos R, Broch M, Megia A, Masdevall $C$, et al. Effect of weight loss induced by gastric bypass on proinflammatory interleukin-18, soluble tumor necrosis factoralpha receptors, C-reactive protein and adiponectin in morbidly obese patients. Clin Endocrinol. 2007;67(5):679-86.

59. Fontana L, Eagon JC, Colonna M, Klein S. Impaired mononuclear cell immune function in extreme obesity is corrected by weight loss. Rejuvenation Res. 2007;10(1):41-6.

60. Hallett WH, Murphy WJ. Positive and negative regulation of natural killer cells: therapeutic implications. Sem Cancer Biol. 2006;16(5):367-82. 